\title{
Upaya Meningkatkan Aktivitas Dan Haassil Belajar Matematika Peserta Didik Kelas V Semester Satu Tahun Pelajaran 2019/2020 di SD Negeri 7 Cakranegara Dengan Menerapkan Model Example Non Example
}

\author{
Ni Nyoman Pujimulyati \\ Guru Kelas V SD Negeri 7 Cakranegara
}

\begin{abstract}
Abstrak. Penelitian ini bertujuan untuk mengetahui efektifitas penerapan pendekatan cooperative learning (CL) tipe Jigsaw dalam upaya meningkatkan aktifitas dan hasil belajar IPA Peserta didik kelas VI SD Negeri 7 Cakranegara. Manfaat penelitian ini adalah sebagai bahan kajian dan bahan temuan dalam pelaksanaan proses pembelajaran di kelas senyatanya. Bagi guru untuk meningkatkan kompetensi dalam proses pembelajaran dan bagi peserta didik untuk meningktakan aktifitas dan hasil belajar peserta didik. Penelitian ini dilaksanakan dua siklus, masing-masing siklus kegiatannya adalah; perencanaan, pelaksanaan, observasi dan refleksi. Hasil akhir tindakan pada siklus II menunjukkan bahwa hasil observasi guru memperoleh skor rata-rata $(4,57)$ dan hasil observasi peserta didik mencapai skor rata-rata $(4,67)$. Sedangkan hasil belajar peserta didik adalah mencapai nilai rata-rata $(84,92)$, artinya indikator keberhasilan $(\geq 75,00)$ telah terlampaui. Karena indikator keberhasilan telah terbukti penelitian dinyatakan berhasil dan dihentikan pada siklus II.
\end{abstract}

Kata Kunci : Aktivitas dan hasil Belajar-Model "Example Non Example"

\section{PENDAHULUAN}

\section{Latar Belakang}

Proses pembelajaran yang berlaku di SD Negeri 7 Cakranegara secara umum sudah mencoba upaya menyongsong abad 21, namun demikian belum semua guru menerapkan. Bagi yang belum melaksanakan beralasan bahwa kemampuan peserta didik untuk berfikir kritis, sistematis, demokratis dan memiliki inovasi tinggi masih jauh dari harapan. Kondisi peserta didik ketika dalam proses pembelajaran kebanyakan masih adem ayem, kalaupun peserta didik itu berbicara itu sifatnya hanya bermain main saja, ada yang bermain pukul pukulan, berteriak teriak tanpa sebab, keluar masuk kelas tanpa seijin guru, dan ada pula yang meludah keluar jendela dan perilaku lain yang kurang terpuji.

Situasi pembelajaran seperti itu dialami pula oleh kebanyakan peserta didik kelas V SD Negeri 7 Cakranegara khususnya pada mata pelajaran matematika. Ketika guru sedang menjelaskan tentang materi pelajaran kondisi peserta didik dapat dipaparkan sebagai berikut: 1) sangat sedikit peserta didik yang menerima pelajaran dengan antusias, mengerjakan dengan sungguh-sungguh tugas diberikan oleh guru baik kerja kelompok maupun tugas individual, 2) kebanyakan peserta didik pada bingung tidak tahu/kurang faham apa yang dikatakan oleh guru selama proses pembelajaran, diberikan tugas baik tugas kelompok maupun tugas individual terkesan cuek. Hal ini disebabkan karena kebanyakan peserta didik tingkat kemampuannya kurang sehingga sangat sulit memahami materi pelajaran, 3) banyak peserta didik selama proses pembelajaran ada yang ribut dan bermain-main dengan teman sejawatnya, ada yang tertidur pulas ditempat duduk, ada yang keluar masuk kelas tanpa ijin dan bahkan ada yang meludah lewat jendela kelas.

Rendahnya aktivitas dan hasil belajar peserta didik kelas V SD Negeri 7 Cakranegara khususnya pada mata pelajaran matematika adalah: a) guru masih belum mampu menunjukkan model pembelajaran yang bisa membangkitkan motivasi belajar secara menyeluruh, artinya semua peserta didik di kelas binaannya merata mampu menyerap materi pelajaran, b) kemampuan intelektual dasar peserta didik rata-rata dibawah standar minimal. Apabila kemampuan dasar rendah, maka sangat sulit menerima materi pelajaran, khususnya mata pelajaran matematika dan extrata yang lainnya, c) tingkat kesadaran peserta didik 
dalam mengikuti pelajaran khususnya mata pelajaran matematika masih rendah, materi yang disampaikan oleh guru masuk telinga kanan keluar telinga kiri artinya belum berdampak positif bagi pertumbuhan intelektualitas peserta didik.

Ada beberapa macam solusi upaya meningkatkan aktivitas dan hassil belajar matematika peserta didik kelas $\mathrm{V}$ semester satu tahun pelajaran 2019/2020 di SD Negeri 7 Cakranegara. Salah satu solusi yang diangkat oleh guru selaku peneliti yaitu dengan menerapkan model pembelajaran "Example Non Example". Model pembelajaran ini berdasarkan pengalaman peneliti mampu meningkatkan aktivitas dan haasil belajar peserta didik. Model pembelajaran ini merupakan salah satu pendekatan "Group Investigation" dalam pembelajaran kooperatif yang dirancang untuk mempengaruhi pola interaksi peserta didik dan meningkatkan aktivitas serta hasil belajar. Model pembelajaran ini dihajatkan untuk pemecahan alternative terhadap model pembelajaran kelas tradisional dan menghendaki peserta didik saling membantu dalam kelompok kecil dan lebih dicirikan oleh penghargaan kooperatif daripada individu.

Model "Example Non Example" ini berdasarkan pengalaman peneliti mempunyai beberapa kelebihan bila dibandingkan dengan model pembelajaran yang lain. Kelebihankelebihan itu adalah: a) Peserta didik berangkat dari satu definisi yang selanjutnya digunakan untuk memperluas pemahaman konsepnya dengan lebih mendalam dan lebih kompleks, b) Peserta didik dilibatkan dalam satu proses discovery (penemuan), yang mendorong mereka untuk membangun konsep secara progresif melalui pengalaman dari example dan non example, c) Peserta didik diberikan sesuatu yang berlawanan dalam mengeksplorasi karakteristik dari suatu konsep dengan mempertimbangkan bagian non example yang dimungkinkan masih terdapat beberapa bagian yang merupakan suatu karakter dari konsep yang telah dipaparkan pada bagian example.
Untuk membuktikan kelebihan model pembelajaran example non example itu maka peneliti mengadakan Penelitian Tindakan Kelas (PTK) dengan judul yang ada korelasinya dengan model pembelajaran example non example yaitu: "Upaya Meningkatkan Aktivitas Dan Haassil Belajar Matematika Peserta Didik Kelas V Semester Satu Tahun Pelajaran 2019/2020 di SD Negeri 7 Cakranegara Dengan Menerapkan Model Example Non Example". Penelitian ini dilakssanakan selama dua siklus. Masingmasing siklus terdiri atas dua kali pertemuan. Masing-massing pertemuan dilaksanakan selama 2 (dua) jam pelajaran $(2 \times 35)=70$ menit.

\section{Rumusan Masalah}

Adapun rumusan masalah dalam Penelitian Tindakan Kelas (PTK) ini adalah: "Bagaimana menerapkan model pembelajaran Example Non Example upaya meningkatkan aktivitas dan hasil belajar matematika peserta didik kelas V Semester Satu Tahun Pelajaran 2019/2020 di SD Negeri 7 Cakranegara?

\section{Tujuan Penelitian}

"Mengetahui sejauh mana efektivitas penerapan model example non example dalam pembelajaran Matematika peserta didik kelas V semester satu tahun pelajaran 2019/2020 upaya meningkatkan aktivitass dan hasil belajar peserta didik di SD Negeri 7 Cakranegara.

\section{Manfaat Penelitian}

a. Manfaat bagi guru

- Dijadikan sebagai bahan kajian akademik khususnya pada mata pelajaran Matematika dengan harapan penerapan model pembelajaran ini menjadi salah satu alternative dalam upaya menumbuhkembangkan karakter peserta didik.

- Dijadikan sebagai bahan untuk kenaikan pangkat kejenjang yang lebih tinggi.

b. Manfaat bagi peserta didik

- Menumbuhkan semangat belajar yang tinggi dan inovatif selama proses pembelajaran di kelas senyatanya.

- Melatih diri untuk percaya diri, rasa ingin tahu, dan mampu merubah 
mindset belajar yang baik, inovatif, serta meningkatkan aktivitas dan hasil belajar.

\section{KAJIAN PUSTAKA \\ Kerangka Teoritis \\ Aktivitas Belajar}

Belajar sangat dibutuhkan adanya aktivitas, dikarenakan tanpa adanya aktivitas proses belajar tidak mungkin berlangsung dengan baik. Pada proses aktivitas pembelajaran harus melibatkan seluruh aspek peserta didik, baik jasmani maupun rohani sehingga perubahan perilakunya dapat berubah dengan cepat, tepat, mudah dan benar, baik berkaitan dengan aspek kognitif afektif maupun psikomotor (Nanang Hanafiah, 2010:23).

Aktivitas belajar adalah aktivitas yang bersifat fisik maupun mental. Dalam proses belajar kedua aktivitas itu harus saling berkaitan. Lebih lanjut lagi piaget menerangkan dalam buku Sardiman bahwa jika seorang anak berfikir tanpa berbuat sesuatu, berarti anak itu tidak berfikir (Sardiman, 2011:100).

Dalam penelitian ini yang dimaksud dengan aktivitas belajar adalah kegiatan peserta didik mengingat, memecahkan masalah, menganalisis faktor-faktor, melihat hubungan-hubungan, dan membuat keputusan terhadap masalah yang diberikan oleh guru kelas V di SD Negeri 7 Cakranegara.

\section{Hasil Belajar}

Masalah belajar adalah masalah bagi setiap manusia, dengan belajar manusia memperoleh keterampilan, kemampuan sehingga terbentuklah sikap dan bertambahlah ilmu pengetahuan. Jadi hasil belajar itu adalah suatu hasil nyata yang dicapai oleh peserta didik dalam usaha menguasai kecakapan jasmani dan rohani di sekolah yang diwujudkan dalam bentuk raport pada setiap semester.

Untuk mengetahui perkembangan sampai di mana hasil yang telah dicapai oleh seseorang dalam belajar, maka harus dilakukan evaluasi. Untuk menentukan kemajuan yang dicapai maka harus ada kriteria (patokan) yang mengacu pada tujuan yang telah ditentukan sehingga dapat diketahui seberapa besar pengaruh strategi belajar mengajar terhadap keberhasilan belajar peserta didik. Hasil belajar peserta didik menurut W. Winkel (dalam buku Psikologi Pengajaran 1989:82) adalah keberhasilan yang dicapai oleh peserta didik, yakni prestasi belajar peserta didik di sekolah yang mewujudkan dalam bentuk angka.

Menurut Winarno Surakhmad (dalam buku, Interaksi Belajar Mengajar, (Bandung: Jemmars, 1980:25) hasil belajar peserta didik bagi kebanyakan orang berarti ulangan, ujian atau tes. Maksud ulangan tersebut ialah untuk memperoleh suatu indek dalam menentukan keberhasilan peserta didik.

Dari definisi di atas, maka dapat
diambil
belajar adalah prestasi belajar yang dicapai peserta didik dalam proses kegiatan belajar mengajar dengan membawa suatu perubahan dan pembentukan tingkah laku seseorang. Untuk menyatakan bahwa suatu proses belajar dapat dikatakan berhasil, setiap guru memiliki pandangan masing-masing sejalan dengan filsafatnya. Namun untuk menyamakan persepsi sebaiknya kita berpedoman pada kurikulum yang berlaku saat ini yang telah disempurnakan, antara lain bahwa suatu proses belajar mengajar tentang suatu bahan pembelajaran dinyatakan berhasil apabila tujuan pembelajaran khususnya dapat dicapai.

Untuk mengetahui tercapai tidaknya tujuan pembelajaran khusus, guru perlu mengadakan tes formatif pada setiap menyajikan suatu bahasan kepada peserta didik. Penilaian formatif ini untuk mengetahui sejauh mana peserta didik telah menguasai tujuan pembelajaran khusus yang ingin dicapai. Fungsi penelitian ini adalah untuk memberikan umpan balik pada guru dalam rangka memperbaiki proses belajar mengajar dan melaksanakan program remedial bagi peserta didik yang belum berhasil. Karena itulah, suatu proses belajar mengajar dinyatakan berhasil apabila hasilnya memenuhi tujuan pembelajaran khusus dari bahan tersebut.

Dalam penelitian ini yang dimaksud dengan hasil belajar adalah laporan individu dan tes dalam bentuk tertulis yang materi soalnya hanya selintas apa yang disajikan 
oleh guru selama prose pembelajaran di kelas. Dalam hal ini adalah materi pembelajaran kelas V.

\section{Model Pembelajaran Example Non Example \\ Model Example non Example adalah} strategi pembelajaran yang menggunakan media gambar dalam penyampaian materi pembelajaran yang bertujuan mendorong siswa untuk belajar berfikir kritis dengan jalan memecahkan permasalahanpermasalahan yang terkandung dalam contohcontoh gambar yang disajikan. Menurut Buehl (1996) dalam Apariani dkk, (2010:20) menjelaskan bahwa examples non examples adalah taktik yang dapat digunakan untuk mengajarkan definisi konsep. Taktik ini bertujuan untuk mempersiapkan siswa secara cepat dengan menggunakan 2 hal yang terdiri dari examples dan non examples dari suatu definisi konsep yang ada dan meminta siswa untuk mengklasifikasikan keduanya sesuai dengan konsep yang ada. Examples memberikan gambaran akan sesuatu yang menjadi contoh akan suatu materi yang sedang dibahas, sedangkan non examples memberikan gambaran akan sesuatu yang bukanlah contoh dari suatu materi yang sedang dibahas.

Model Pembelajaran Examples non Examples menggunakan gambar sebagai media pembelajaran. Media gambar merupakan salah satu alat yang digunakan dalam proses belajar mengajar yang dapat membantu mendorong siswa lebih melatih diri dalam mengembangkan pola pikirnya. Dengan menerapkan media gambar diharapkan dalam pembelajaran dapat bermanfaat secara fungsional bagi semua siswa. Sehingga dalam kegiatan pembelajaran siswa diharapkan akan aktif dan semangat untuk belajar.

Examples non examples merupakan model pembelajaran dengan mempersiapkan gambar, diagram, atau tabel sesuai materi bahan ajar dan kompetensi, sajian gambar ditempel atau memakai LCD/OHP, dengan petunjuk guru siswa mencermati sajian, diskusi kelompok tentang sajian gambar tadi, presentasi hasil kelompok, bimbingan penyimpulan, evaluasi, dan refleksi (Roestiyah. 2001: 73). Sementara itu, Slavin dalam Djamarah, (2006: 1) dijelaskan bahwa Examples Non Examples adalah model pembelajaran yang menggunakan contoh. Contoh-contoh dapat diperoleh dari kasus atau gambar yang relevan dengan Kompetensi Dasar.

Langkah-Langkah Model Pembelajaran Examples Non Examples

Menurut (Agus Suprijono, 2009 : 125) Langkah - langkah model pembelajaran Examples Non Examples, diantaranya:

a. Guru mempersiapkan gambar-gambar sesuai dengan tujuan pembelajaran. Gambar- gambar yang digunakan tentunya merupakan gambar yang relevan dengan materi yang dibahas sesuai dengan Kompetensi Dasar.

b. Guru menempelkan gambar di papan atau ditayangkan melalui LCD/OHP/In Focus pada tahap ini Guru dapat meminta bantuan siswa untuk mempersiapkan gambar dan membentuk kelompok siswa.

c. Guru memberi petunjuk dan kesempatan kepada peserta didik untuk memperhatikan/

menganalisa gambar. Peserta didik diberi waktu melihat dan menelaah gambar yang disajikan secara seksama agar detil gambar dapat dipahami oleh peserta didik, dan guru juga memberi deskripsi tentang gambar yang diamati.

d. Melalui diskusi kelompok 2-3 orang siswa, hasil diskusi dari analisa gambar tersebu dicatat pada kertass . Kertas yang digunakan sebaiknya disediakan guru.

e. Tiap kelompok diberi kesempatan untuk membacakan hasil diskusinya. dilatih peserta didik untuk menjelaskan hasil diskusi mereka melalui perwakilan kelompok masing masing.

f. Mulai dari komentar/hasil diskusi peserta didik, guru mulai menjelaskan materi sesuai dengan tujuan yang ingin dicapai

g. Guru dan peserta didik menyimpulkan materi sesuai dengan tujuan pembelajaran. 


\section{Kerangka Konseptual}

Hubungan antara variabel harapan (meningkatnya aktivitas dan hasil belajar peserta didik) dengan variabel tindakan (penerapan model pembelajaran Example Non Example).

\section{Hipotesis Tindakan}

"Penerapan model pembelajaran Example Non Example dapat meningkatkan aktivitas dan hasil belajar peserta didik kelas V SD Negeri 7 Cakranegara Semester Satu Tahun Pelajaran 2019/2020".

\section{METODE PENELITIAN}

\section{Setting Penelitian}

Penelitian tindakan kelas (PTK) ini akan dilaksanakan di kelas V SD Negeri 7 Cakranegara Semester Satu Tahun Pelajaran 2019/2020, dengan jumlah peserta didik sebanyak 36 orang.

\section{Faktor yang Diteliti}

1. Faktor Guru: yaitu dengan mengamati cara guru membuat Rencana Pelaksanaan Pembelajaran (RPP) dan pelaksanaannya dalam pembelajaran di kelas senyatanya dengan menerapkan model pembelajaran Example Non Example dalam upaya meningkatkan aktivitas dan hasil belajar peserta didik Kelas V SD Negeri 7 Cakranegara.

2. Faktor Peserta didik: yaitu peningkatan aktivitas belajar peserta didik yang terlihat pada saat melaksanakan diskusi kelompok, dan pada saat tes tertulis di akhir pembelajaran bagi peserta didik kelas V Semester Satu Tahun Pelajaran 2019/2020 di SD Negeri 7 Cakranegara.

\section{Rencana Tindakan}

kegiatan nyata di kelas $\mathrm{V}$ yaitu melaksanakan proses pembelajaran dengan menerapkan model pembelajaran Example Non Example dalam upaya meningkatan aktivitas dan hasil belajar peserta didik kelas V SD Negeri 7 Cakranegara Semester Satu Tahun Pelajaran 2019/2020. Tindakan nyata yang dilakukan oleh guru selaku peneliti adalah dengan menggunakan siklus.
Gambaran siklus dalam penelitian ini adalah sebagai berikut:

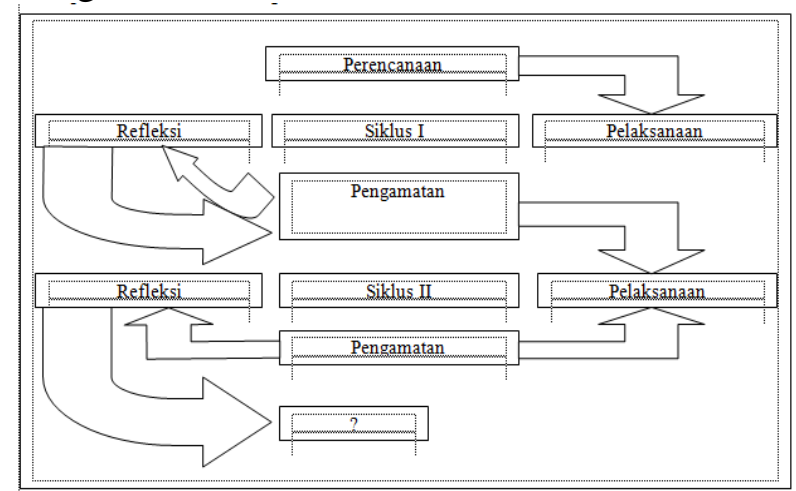

Setiap siklus selama penelitian ini berisi 4 (empat) tahapan yaitu: 1) Perencanaan (Planning), 2) Pelaksanaan (Action), 3) Observasi (Observation), dan 4) Refleksi (Reflection).

\section{Siklus Tindakan SIKLUS I}

1) Tahap Perencanaan (Planning)

Pada tahapan ini guru selaku peneliti melakukan kegiatan-kegiatan sebagai berikut:

1. Menyusun Rencana Pelaksanaan Pembelajaran (RPP) dengan skenario sesuai dengan aturan main model pembelajaran Example Non Example.

2. Menyiapkan sumber, bahan, dan semua alat yang digunakan dalam penelitian.

3. Menyusun/membuat lembar observasi guru dan lembar observasi peserta didik.

4. Menyusun alat evaluasi.

\section{2) Tahap Pelaksanaan (Action)}

\section{Pertemuan I}

1. Guru mempersiapkan gambar-gambar sesuai dengan tujuan pembelajaran. Gambar- gambar yang digunakan tentunya merupakan gambar yang relevan dengan materi yang dibahas sesuai dengan Kompetensi Dasar.

2. Guru menempelkan gambar di papan atau ditayangkan melalui LCD/OHP/In Focus pada tahap ini Guru dapat meminta bantuan siswa untuk mempersiapkan gambar dan membentuk kelompok siswa.

3. Guru memberi petunjuk dan kesempatan kepada peserta didik untuk 
memperhatikan/

menganalisa gambar. Peserta didik diberi waktu melihat dan menelaah gambar yang disajikan secara seksama agar detil gambar dapat dipahami oleh peserta didik, dan guru juga memberi deskripsi tentang gambar yang diamati.

4. Melalui diskusi kelompok 2-3 orang siswa, hasil diskusi dari analisa gambar tersebu dicatat pada kertass . Kertas yang digunakan sebaiknya disediakan guru.

\section{Pertemuan II}

5. Tiap kelompok diberi kesempatan untuk membacakan hasil diskusinya. dilatih peserta didik untuk menjelaskan hasil diskusi mereka melalui perwakilan kelompok masing masing.

6. Mulai dari komentar/hasil diskusi peserta didik, guru mulai menjelaskan materi sesuai dengan tujuan yang ingin dicapai

7. Guru dan peserta didik menyimpulkan materi sesuai dengan tujuan pembelajaran.

8. Tes Tertulis

3) Tahap Observasi (Observation)

1. Observasi guru :

Dilakukan oleh pengawas pembimbing dalam melaksanakan Penelitian Tindakan Kelas (PTK).

2. Observasi Peserta didik :

Dilakukan oleh guru kelas sebagai peneliti dalam Penelitian Tindakan Kelas (PTK) pada kegiatan diskusi kelompok dan presentasi kelompok.

\section{4). Tahap Refleksi (Reflection)}

1. Renungan hasil perolehan data

2. Pengolahan dan analisa data hasil penelitian

3. Mencocokkan hasil analisa data dengan indikator keberhasilan

4. Rencana perbaikan dan tindak lanjut

\section{SIKLUS II}

Pada siklus ini semua kegiatan dan tahapan selama penelitian adalah sama, sifatnya mengulang dan memperbaiki terhadap tindakan yang masih memerlukan penyempurnaan dan pembenaran sebagaimana mestinya.

\section{Data dan Cara Pengambilannya. Sumber Data}

Yang menjadi sumber data dalam penelitian tindakan kelas (PTK) ini adalah semua peserta didik kelas V SD Negeri 7 Cakranegara Semester Satu Tahun Pelajaran 2019/2020 dan guru kelas/mata pelajaran .

\section{Jenis Data}

- Jenis data yang berasal dari guru selaku peneliti

1). Data tentang Rencana Pelaksanaan Pembelajaran (RPP)

2). Data Pelaksanaan Pembelajaran

- Jenis data yang berasal dari peserta didik :

1). Data kemajuan aktivitas belajar

2). Data hasil laporan individu hasil diskusi kelompok

3). Data hasil belajar peserta didik/tes tertulis

\section{Cara Pengambilan data}

- Data kegiatan pembelajaran diambil dari RPP yang dibuat oleh guru dan lembar observasi pelaksanaan model pembelajaran Example Non Example

- Data kemajuan aktivitas belajar; diambil dari lembar observasi selama kerja kelompok dan presentasi kelompok.

- Data kemajuan hasil belajar; diambil dari laporan hasil kerja kelompok secara individual dan nilai hasil tes tertulis yang dilaksanakan pada akhir proses pembelajaran

\section{Indikator Keberhasilan dan Teknik analisa data \\ Teknik analisa data}

Untuk menganalisis data akan dilakukan melalui analisis deskriptif kuantitatif melalui pendataan, analisis dan pembahasan terhadap data yang diperoleh dengan mencocokkan tingkat keoptimalan terhadap capaian indikator keberhasilan yang ada.

\section{Indikator Keberhasilan}

1. guru telah dinyatakan berhasil melaksanakan proses pembelajaran dengan pendekatan Example Non Example, bila telah mencapai skor rata-rata $\geq 4,00$

2. aktivitas belajar peserta didik kelas $\mathrm{V}$ dinyatakan telah meningkat jika $\geq$ 
$85 \%$ dari jumlah peserta didik telah memperoleh skor rata-rata $\geq 4,0$ (kategori baik) dan hasil belajar dinyatakan telah meningkat jika $\geq$ $85 \%$ dari jumlah peserta didik memperoleh nilai rata-rata $\geq 75,00$ (KKM Peserta didik).

\section{HASIL DAN PEMBAHASAN}

\section{Laporan Hasil}

\section{DESKRIPSI SIKLUS I}

\section{Tahap Perencanaan}

Pada tahapan ini yang telah dilakukan oleh guru selaku peneliti adalah; 1) menyusun RPP dengan skenario pembelajaran Example non example, 2) telah berhasil menyiapkan alat, sumber, bahan yang diperlukan dalam penelitian, 3) berhasil menyusun instrument observasi guru dan instrument observasi peserta didik, dan 4) menyusun alat evaluasi.

\section{Tahap Pelaaksanaan \\ Pertemuan I}

1. Guru mempersiapkan gambar-gambar sesuai dengan tujuan pembelajaran. Gambar- gambar yang digunakan tentunya merupakan gambar yang relevan dengan materi yang dibahas sesuai dengan Kompetensi Dasar.

2. Guru menempelkan gambar di papan atau ditayangkan melalui LCD/OHP/In Focus pada tahap ini Guru dapat meminta bantuan siswa untuk mempersiapkan gambar dan membentuk kelompok siswa.

3. Guru memberi petunjuk dan kesempatan kepada peserta didik untuk memperhatikan/ menganalisa gambar. Peserta didik diberi waktu melihat dan menelaah gambar yang disajikan secara seksama agar detil gambar dapat dipahami oleh peserta didik, dan guru juga memberi deskripsi tentang gambar yang diamati.

4. Melalui diskusi kelompok 2-3 orang siswa, hasil diskusi dari analisa gambar tersebu dicatat pada kertass . Kertas yang digunakan sebaiknya disediakan guru.

\section{Pertemuan II}

5. Tiap kelompok diberi kesempatan untuk membacakan hasil diskusinya. dilatih peserta didik untuk menjelaskan hasil diskusi mereka melalui perwakilan kelompok masing masing.
6. Mulai dari komentar/hasil diskusi peserta didik, guru mulai menjelaskan materi sesuai dengan tujuan yang ingin dicapai

7. Guru dan peserta didik menyimpulkan materi sesuai dengan tujuan pembelajaran.

8. Tes Tertulis

\section{Tahap Observasi}

Observasi guru memperoleh skor rata-rata pertemuan I $(3,36)$ dan pertemuan II $(3,71)$, observasi peserta didik memperoleh skor ratarata pertemuan I $(3,43)$ dan pertemuan II $(3,69)$. Hasil belajar diambil dari hasil tugas individual dan tes tertulis memperoleh nilai rata-rata masing-masing sebesar $(66,19)$ dan 68,03).

\section{Tahap Refleksi}

1. Renungan data hasil perolehan data pada siklus I

2. Pengolahan data hasil observasi guru, peserta didik dan tes tertulis.

3. Mencocokkan hasil yang ada dengan Indikator keberhasilan.

4. Merencanakan perbaikan terhadap jenis tindakan yang menyebabkan belum tuntas Indikator keberhasilan. Oleh karena Indikator keberhasilan belum terbukti maka penelitian dilanjutkan ke siklus II.

\section{DESKRIPSI SIKLUS II \\ Tahap Perencanaan}

Pada tahapan ini jenis kegiatan yang dilakukan masih mengacu pada kegiatan siklus I, bedanya hanya terjadi perbaikan seperlunya yaitu: 1) penyusunan RPP dengan mengacu pada pendekatan Example non example dan penyempurnaan pada bagian skenario pembelajaran, 2) menyiapkan alat, sumber, bahan yang diperlukan dalam proses tindakan dikelas senyatanyan, 3) menyiapkan lembar observasi guru dan lembar observasi peserta didik sebagaimana pada siklus I, 4) menyiapkan alat evaluasi sebagaimana yang telah dibuat pada siklus I.

\section{Tahap Pelaksanaan}

Secara umum tahapan pelaksanaan proses pembelajaran pada siklus II ini masih mengacu pada pelaksanaan proses pembelajaran sebelumnya. Yang dilakukan pada proses pembelajaran ini adalah: 1) pelaksanaan proses diskusi kelompok kecil lebih dioptimalkan, 2) pelaksanaan 
pembimbingan kelompok sekaligus observasi peserta didik lebih di efektifkan. Utamanya pengamatan peserta didik yang aktif, yang kurang aktif, peserta didik yang tidak aktif, dengan harapan proses analisa data lebih signifikan, 3)laporan hasil kerja kelompok yang dibuat secara individu lebih difokuskan, dan 4) pelaksanaan tes tertulis sebagai tolak ukur keberhasilan peserta didik lebih dioptimalkan.

\section{Tahap Observasi}

Observasi guru memperoleh skor rata-rata pertemuan I $(4,14)$ dan pertemuan II $(4,57)$, observasi peserta didik memperoleh skor ratarata pertemuan I $(4,42)$ dan pertemuan II $(4,61)$. Hasil belajar diambil dari hasil tugas individual dan tes tertulis memperoleh nilai rata-rata masing-masing sebesar $(86,67)$ dan $(84,92)$.

\section{Tahap Refleksi}

1. Renungan atas perolehan data hasil observasi guru, observasi peserta didik, dan hasil tes tertulis sebagai hasil dari peningkatan aktivitas dan hasil belajar peserta didik di kelas senyatanya.

2. Pengolahan data hasil observasi guru, observasi peserta didik dan tes tertulis

3. Mencocokkan perolehan data hasil tindakan dengan Indikator keberhasilan yang telah ditetapkan.

4. Guru memberikan hadiah/reward kepada semua peserta didik kelas $\mathrm{V}$ atas keberhasilannya dalam upaya meningkatkan aktivitas dan hasil belajar dan perolehan hasil belajar sesuai dengan KKM yang telah ditetapkan.

\section{Pembahasan \\ SIKLUS I}

\section{Tahap Perencanaan}

Pada tahapan ini kegiatan yang dilakukan adalah menyusun RPP, menyiapkan alat, sumber, bahan yang diperlukan dalam proses pembelajaran, menyusun instrument observasi guru maupun instrument observasi Peserta didik. Ada beberapa kendala yang dihadapi, tetapi setelah meminta petunjuk dan arahan kepada pembimbing kendala pun dapat diatasi dengan baik.

\section{Tahap Pelaksanaan}

1. Guru mempersiapkan gambar-gambar sesuai dengan tujuan pembelajaran.
Gambar- gambar yang digunakan tentunya merupakan gambar yang relevan dengan materi yang dibahas sesuai dengan Kompetensi Dasar.

2. Guru menempelkan gambar di papan atau ditayangkan melalui LCD/OHP/In Focus pada tahap ini Guru dapat meminta bantuan siswa untuk mempersiapkan gambar dan membentuk kelompok siswa.

3. Guru memberi petunjuk dan kesempatan kepada peserta didik untuk memperhatikan/

menganalisa gambar. Peserta didik diberi waktu melihat dan menelaah gambar yang disajikan secara seksama agar detil gambar dapat dipahami oleh peserta didik, dan guru juga memberi deskripsi tentang gambar yang diamati.

4. Melalui diskusi kelompok 2-3 orang siswa, hasil diskusi dari analisa gambar tersebu dicatat pada kertass . Kertas yang digunakan sebaiknya disediakan guru.

5. Tiap kelompok diberi kesempatan untuk membacakan hasil diskusinya. dilatih peserta didik untuk menjelaskan hasil diskusi mereka melalui perwakilan kelompok masing masing.

6. Mulai dari komentar/hasil diskusi peserta didik, guru mulai menjelaskan materi sesuai

dengan tujuan yang ingin dicapai

7. Guru dan peserta didik menyimpulkan materi sesuai dengan tujuan pembelajaran.

Kegiatan pembelajaran diakhiri dengan tes tertulis, hal ini dimaksudkan untuk mengetahui peningkatan hasil belajar peserta didik kelas V SD Negeri 7 Cakranegara Semester Satu Tahun Pelajaran 2019/2020 dengan penerapan model pembelajaran Example Non Example. Asumsi bila aktivitas dan hasil belajar meningkat maka akan terjadi peningkatan hasil belajar pula.

\section{Tahap Observasi}

Observasi guru memperoleh skor ratarata pertemuan I $(3,36)$ dan pertemuan II $(3,71)$, sementara Indikator keberhasilan yang diharapkan $(\geq 4,0)$. Hasil observasi peserta didik dalam upaya peningkatan aktivitas dan hasil belajar peserta didik kelas V Semester Satu Tahun Pelajaran 2019/2020 di SD Negeri 7 Cakranegara diperoleh skor 
rata-rata pertemuan I $(3,43)$ dan pertemuan II $(3,69)$. Perolehan nilai rata-rata tugas individual dan tes tertulis yang dilakukan pada akhir pelajaran adalah $(66,19)$ dan $(68,03)$ kategori cukup.

\section{Tahap Refleksi}

Hasil analisa data perolehan aktivitas dan hasil belajar pada siklus I ini $(3,69)$ sedangkan yang diminta dalam Indikator keberhasilan $(\geq 4,0)$, ini artinya belum berhasil.

Karena Indikator keberhasilan belum tercapai, penelitian tindakan kelas (PTK) dilanjutkan ke siklus II dengan harapan optimalisasi penerapan strategi pembelajaran dengan pendekatan Example non example dapat meningkatkan aktivitas dan hasil belajar peserta didik kelas V Semester Satu Tahun Pelajaran 2019/2020 di SD Negeri 7 Cakranegara.

\section{SIKLUS II}

\section{Tahap Perencanaan}

Peneliti menyusun Rencana Pelaksanaan Pembelajaran (RPP) dengan memperhatikan kesalahan-kesalahan pada siklus I. peneliti lebih memfokuskan tentang Rencana strategi jitu sehingga proses pembelajaran dengan model pembelajaran Example Non Example dapat terelaisasi dengan baik, karenanya dalam penyusunan skenario benar-benar dirinci dari tiap aspek pada proses pembelajaran dengan example non example.

Sebelum proses pembelajaran dilaksanakan, peneliti menyiapkan semua alat, bahan, dan segala sesuatunya sehingga dalam pelaksanaan proses pembelajaran berjalan sesuai dengan skenario yang telah direncanakan. Agar proses pembelajaran dapat teratasi maka peneliti juga menyiapkan lembar observasi guru dan lembar observasi peserta didik sebagai tolak ukur ketercapaian peningkatan aktivitas dan hasil belajar peserta didik kelas V SD Negeri 7 Cakranegara.

\section{Tahap Pelaksanaan}

Pada tahap pelaksanaan di siklus II ini pada dasarnya masih mengacu pada pelaksanaan siklus I, yaitu penerapan model pembelajaran Example Non Example. Bedanya pada siklus ini lebih dioptimalkan.

\section{Tahap Observasi}

Pada siklus II ini hasil observasi memperoleh skor rata-rata pertemuan I $(4,14)$ dan pertemuan II $(4,57)$. Upaya meningkatkan aktivitas dan hasil belajar peserta didik kelas V Semester Satu Tahun Pelajaran 2019/2020 di SD Negeri 7 Cakranegara diperoleh skor rata-rata pertemuan I $(4,42)$ pertemuan II $(4,61)$, dampak nyata dari meningkatnya aktivitas dan hasil belajar adalah prestasi belajar juga meningkat, dari data hasil perolehan nilai tugas dan rata-rata tes tertulis adalah $(86,67)$ dan $(84,92)$ sementara pada siklus sebelumnya hanya $(66,19)$ dan $(68,03)$ berarti mengalami peningkaatan yang signifikan .

\section{Tahap Refleksi}

Hasil analisa data peningkatan aktivitas dan hasil belajar peserta didik pada siklus II adalah $(4,61)$ sedangkan Indikator keberhasilan $(\geq 4,0)$. Ini artinya pada siklus II hasilnya telah melampaui Indikator keberhasilan. Hasil belajar pada siklus I $(67,11)$ sedangkan pada siklus II $(85,79)$, ini artinya indikator keberhasilan telah dilampaui.

Karena Indikator keberhasilan telah terbukti, maka tidak perlu ada upaya perbaikan dan penyempurnaan. Model pembelajaran Example Non Example telah mampu meningkatkan aktivitas dan hasil belajar peserta didik yang ditandai dengan tercapainya Indikator keberhasilan dan terjadinya peningkatan hasil belajar peserta didik. "Penelitian Tindakan Kelas (PTK) dihentikan pada siklus II dengan hasil memuaskan."

\section{SIMPULAN DAN SARAN}

Simpulan

Data komulatif dari hasil penelitian tindakan kelas (PTK) dari siklus I ke Siklus II adalah sebagai berikut:

\begin{tabular}{|c|l|c|c|c|c|c|c|}
\hline \multirow{2}{*}{ No } & \multirow{2}{*}{ Jenis Kegiatan } & \multirow{2}{*}{$\begin{array}{c}\text { Indikator } \\
\text { Keberhasilan }\end{array}$} & \multicolumn{2}{|c|}{ Siklus I } & \multicolumn{2}{|c|}{ Siklus II } & \multirow{2}{*}{ Ket } \\
\cline { 4 - 7 } & & A & B & A & B & \\
\hline 1. & Hasil Observaasi Guru & $\geq 4,00$ & 3,36 & 3,71 & 4,14 & 4,57 & Tuntas \\
\hline 2. & Observasi Peserta didik & $\geq 4,00$ & 3,43 & 3,69 & 4,42 & 4,61 & Tuntas \\
\hline 3. & Hasil Tugas Individual & $\geq 75,00$ & 66,19 & 86,67 & Tuntas \\
\hline 4. & Hasil Tes tertulis & $\geq 75,00$ & \multicolumn{2}{|c|}{68,03} & 84,92 & Tuntas \\
\hline
\end{tabular}

Penerapan pendekatan cooperative learning (CL) tipe Jugsaw sangat efektif 
dalam upaya untuk meningkatkan aktivitas dan hasil dan hasil belajar peserta didik kelas V Semester Satu Tahun Pelajaran 2019/2020 di SD Negeri 7 Cakranegara. Fakta telah menunjukkan perolehan rata-rata skor aktivitas dan hasil belajar peserta didik pada siklus I $(3,43)$, sedangkan pada siklus II $(4,61)$, hasil belajar dari 67,11 menjadi 85,79 sudah melampaui Indikator keberhasilan yang ditetapkan. Penelitian dinyatakan "berhasil" dan dihentikan pada siklus II.

\section{Saran-Saran}

Disarankan kepada guru sejawat untuk melaksanakan Penelitian Tindakan Kelas (PTK) dalam upaya untuk meningkatkan aktivitas dan hasil dan hasil belajar peserta didik sesuai dengan mata pelajaran masingmasing.

Disarankan kepada para semua peserta didik kelas V SD Negeri 7 Cakranegara untuk membiasakan belajar dengan pendekatan yang kontekstual utamanya strategi yang mampu membangkitkan aktivitas dan hasil dan hasil belajar peserta didik yang dampaknya prestasi belajar dapat ditingkatkan seperti yang diharapkan.

\section{DAFTAR PUSTAKA}

Anonim, 2019, dalam https://bagawanabiyasa.wordpress.co m/2016/01/08/metode-examples-nonexamples/, diambil tanggal 14 Juli 2019, pukul 11.46 Wita.

Anonim, 2019, dalam https://ekokhoerul.wordpress.com/201 2/06/27/konsep-aktivitas-belajarsiswa/, diambil tanggal 16 Juli 2019, pukul 13.46 Wita.

Anonim, 2097, dalam http://ainamulyana.blogspot.co.id/201 2/01/pengertian-hasil-belajar-danfaktor.html, diambil tanggal 16 Juli 2019, Pukul 14.54 Wita

Al Hakim, S dan Riyanto, M, 2002, strategi Pembelajaran Berdasarkan Deep Dialogue/Critical Thinking (DD/CT), Malang: PPPG IPS dan PMP

Arikunto, s. 2009, Penelitian Tindakan Kelas, Jakarta : Bumi Aksara.
Harun Rasyid dan Mansur, 2008, Penilaian Hasil Belajar, Bandung : CV Wacana Prima.

Lie, A, 2002, Cooperative Learning, Jakarta: Gramedia Widiasarma Indonesia.

Lukmanul A, 2008, Perencanaan Pembelajaran, Bandung : CV Wacana Prima.

Mukhtar, 2003, Prosedur Penilaian, Jakarta : Rineka Cipta.

Nurhadi, 2003, Yasin ,B dan Sendule.A, 2003, Kontekstual dan Penerapannya dalam KBK, Malang : Unitipetas Negeri Malang.

Robert E Slavin, 2010, Cooperative Learning Teori, riset dan Praktik, Bandung : Nusa Media.

Sardiman, 2007, Indikator Dan Aktivitas dan hasil Belajar Mengajar, Jakarta : Raja Grafindo Perkasa.

Supriono, 2009, Cooperative Learning Teori dan Aplikasi PAIKEM, Yogyakarta : Pustaka Pelajar. 